\title{
An Evaluation of Provoked Vulvodynia, Pelvic Floor Muscles and Sexual Functions in Female Patients with Fibromyalgia Syndrome
}

\author{
Fibromyalji Sendromu Olan Kadın Hastalarda Provake Vulvodini, Pelvik Taban Kasları ve \\ Seksüel Fonksiyonların Değerlendirilmesi
}

\author{
Hatice Reşorlu, Fatma Beyazıt*, Davut Döner, Sibel Oymak**, Coşkun Zateri \\ Çanakkale Onsekiz Mart University Faculty of Medicine, Department of Physical Medicine and Rehabilitation, Çanakkale, Turkey \\ ${ }^{*}$ Çanakkale Onsekiz Mart University Faculty of Medicine, Department of Obstetrics and Gynecology, Çanakkale, Turkey \\ **Çanakkale Onsekiz Mart University Faculty of Medicine, Department of Public Health, Çanakkale, Turkey
}

\section{Abstract}

Objective: The aim of our study is to investigate the genital origin of pain, particularly provoked vulvodynia (PVD) in female patients with Fibromyalgia syndrome (FMS), to reveal the relationship between PVD and pelvic floor muscle functions and to evaluate patients' sexual functions.

Materials and Methods: Twenty four female patients who were diagnosed with FMS and who had not yet been treated, sexually active and 24 control cases were included to study. Severity of dyspareunia and dysmenorrhea was evaluated with a visual analogue scale, PVD was assessed using the cotton swab exam of vulva and sexual functions were evaluated with using the Female Sexual Function Index (FSFI). Additionally, pelvic floor muscles were graded using Brink scoring.

Results: The severity means of menstrual term pain and dyspareunia severity were significantly higher in the patients than the control group $(p=0.003, p=0.006)$. Significant differences were observed between the patient and control group in terms of vulvar pain in cotton swab exam and total Brink scores (both $p<0.001$ ). FSFI score was lower in the patient group than in the control group ( $p=0.001)$. A powerful correlation in the negative direction was determined between the result of cotton swab exam and Brink score $(p<0.001, r=-0.575)$.

Conclusion: The result of our study showed that dysmenorrhea, dyspareunia and PVD were significantly high in the FMS patients than in the control group. Pelvic floor muscle functions were affected in the FMS patients, and PVD was closely associated with the pelvic floor muscle functions.

Keywords: Fibromyalgia syndrome, provoked vulvodynia, pelvic floor muscle functions

\section{$\ddot{O z}$}

Amaç: Çalışmamızın amacı Fibromiyalji sendromlu (FMS) kadın hastalarda başta provoke vulvodini (PVD) olmak üzere genital kaynaklı ağrıları araştırmak, PVD ile pelvik taban kas fonksiyonları arasındaki ilişkiyi ortaya koymak ve hastaların seksüel fonksiyonlarını değerlendirmektir. Gereç ve Yöntem: Çalışmamıza FMS tanısı alan ve henüz tedavi başlanmamış, cinsel olarak aktif, 24 kadın hasta ve 24 kontrol olgusu kabul edildi. Disparoni ve dismenore şiddeti visual analog skala ile, PVD vulvanın pamuklu çubuk muayenesi ile, cinsel fonksiyonlar Kadın Cinsel İşlev Ölçeği (FSFI) ile değerlendirildi. İlaveten pelvik taban kasları Brink skorlaması kullanılarak derecelendirildi.

Bulgular: Hastalarda menstrüel dönemdeki ağıı ve disparoni şiddeti ortalamaları kontrol grubuna göre anlamlı olarak yüksek bulundu $(p=0,003, p=0,006)$. Hasta ve kontrol grubu arasında pamuklu çubuk muayenesinde vulvar ağrı ve toplam Brink skorları açısından belirgin farklılık mevcuttu (her ikisi de $p<0,001)$. FSFI skoru kontrol grubunda hasta grubuna göre daha düşüktü $(p=0,001)$. Pamuklu çubuk muayenesi sonucu ile Brink skoru arasında negatif yönde güçlü bir korelasyon saptandı $(p<0,001, r=-0,575)$.

Sonuç: Çalışmamızın sonuçları FMS hastalarında dismenore, disparoni ve PVD'nin kontrol grubuna göre anlamlı oranda daha fazla olduğunu gösterdi. FMS hastalarında pelvik taban kas fonksiyonları etkilenmişti ve PVD ile pelvik taban kas fonksiyonları yakından ilişkiliydi.

Anahtar kelimeler: Fibromiyalji sendromu, provoke vulvodini, pelvik taban kas fonksiyonları

Address for Correspondence/ Yazışma Adresi: Hatice Reşorlu MD, Çanakkale Onsekiz Mart University Faculty of Medicine, Department of Physical Medicine and Rehabilitation, Çanakkale, Turkey

Phone: +90 5054548721 E-mail: drresorlu@gmail.com ORCID ID: orcid.org/0000-0001-9889-1064 Received/Geliş Tarihi: 09.10.2017 Accepted/Kabul Tarihi: 05.03.2018

${ }^{\circ}$ Copyright 2017 by the Turkish Osteoporosis Society

Turkish Journal Of Osteoporosis published by Galenos Yayınevi. 


\section{Introduction}

Fibromyalgia syndrome (FMS) is a disease characterized by diffuse musculoskeletal pain. It is generally seen in women aged 20-55 years, and pain is accompanied by symptoms such as fatigue, morning stiffness, sleep disorders, depression and anxiety $(1,2)$. It is seven times more common in females than in males (3). The alteration in pain perception in FMS assumes the form of allodynia and hyperalgesia. Other central sensitization system symptoms with chronic pain such as headache, irritable bowel syndrome, temporomandibular disorders, interstitial cystitis and vulvar vestibular syndrome may also accompany FMS (3).

Vulvodynia is a complex and difficult to treat disorder seen in $16 \%$ of women in the general population. It is thought to be an expression of chronic, diffuse pain syndromes $(4,5)$. The principal finding is a sensation of discomfort in the vulva and pain, particularly of a burning character. It is classified as provoked, unprovoked or mixed type. Various factors, such as developmental anomalies in the early fetal period, genetic and immune factors, hormonal factors, inflammation, infection, neurological changes and oxalate in diet have been implicated in the etiology (5). Dysfunction in the pelvic floor muscles has also been determined in women with vulvodynia (6).

Our study investigated the relationship between provoked vulvodynia (PVD), pelvic floor muscle functions and sexual functions in patients with FMS.

\section{Materials and Methods}

Twenty-four sexually active women presenting to our hospital's physical medicine and rehabilitation clinic were included in the study. The study population was selected from among cases diagnosed with FMS on the basis of 1990 American College of Rheumatology criteria but who had not yet started treatment. Twenty-four subjects in a similar age group and consenting to gynecological examination were enrolled as the control group. Postmenopausal period, oral contraceptive use, history of any gynecological disease or surgery, history of dermatological disease or allergy or presence of systemic-psychiatric disease were adopted as exclusion criteria.

The Local Ethics Committee of Çanakkale Onsekiz Mart University Faculty of Medicine approved the study and written informed consent was taken from each patient (date: 14.05.2014 no: 2014-09/05).

The patient and control group socio-demographic characteristics were first investigated. Next, general body pain was scored using a 100-mm visual analogue scale (VAS). The degree to which patients were affected by the disease was assessed using the Fibromyalgia Impact Questionnaire (FIQ), which enquires into 10 separate features and on which higher scores indicate higher impact (7).

Dyspareunia and dysmenorrhea in the patient and control groups were measured using a 10-cm VAS. Avoidance of sexual intercourse due to dyspareunia was classified under three groups; group 1, no avoidance, group 2 moderate avoidance and group 3 severe avoidance.

Sexual functions in the patient and control groups were evaluated using the Female Sexual Function Index (FSFI) consisting of 19 items (8).

Both groups underwent gynecological examination by a specialist gynecologist. During this examination the vulva was touched at the 2, 4, 6, 8 and 10 points of the clock using the cotton swab exam, and patients were asked about the presence of pain (9). The pelvic floor muscles was also evaluated using the Kegel maneuver (bimanual examination) and Brink scoring. During this examination in pelvic floor muscles, muscle contraction (1: no response, 2: weak squeeze, 3 : moderate squeeze, 4: strong squeeze), duration of muscle contraction (1: none, 2: 1 second, 3: 1-3 seconds, 4: 3 seconds) and vertical displacement (1: none, 2: "finger base moves anteriorly", 3: whole length of fingers move anteriorly, 4: whole fingers move anteriorly, are gripped and pulled in were classified) Ratings are summed to obtain total scores. Higher scores were regarded as indicating better muscle function (10).

\section{Statistical Analysis}

The data obtained were analyzed on SPSS 20.0 software. Normal distribution of variables was examined using the Shapiro-Wilk test. Descriptive data were expressed as mean, standard deviation, frequency and percentage values. The chisquare test was used to compare categoric variables between the patient and control groups and the Independent Samples t-test to compare mean values. Relations between variables were examined using Spearman's and Pearson's correlation tests. Statistical significance was set at p values lower than 0.05 .

\section{Results}

Twenty-four patients diagnosed with FMS and 24 healthy controls were included in the study. Mean ages of the patient and control groups were $39.00 \pm 5.39$ years (minimum: 27-maximum: 47) and 37.29 \pm 4.68 (minimum: 29-maximum: 50) years, respectively. The difference was not significant $(p=0.175)$. Mean body mass index (BMI) was 26.77 \pm 6.22 in the patient group and $26.14 \pm 4.08$ in the control group. Mean duration of disease was $4.67 \pm 4.47$ years.

Demographic characteristics such as age, BMI, smoking status and number of children were similar between the patient and control groups (Table 1).

In the patient group, the mean FIQ score was 58.34 \pm 17.40 and the mean VAS score for musculoskeletal pain was $67.91 \pm 16.21$. Severity of dysmenorrhea and dyspareunia were significantly higher in the patients compared to the control group ( $p=0.003$ and $p=0.006$, respectively). FSFI score was lower in the patient group than in the control group $(p=0.001)$ (Table 2$)$. Sexual dysfunction was determined in 20 patients (83.3\%) and in nine of the control cases (37.5\%).

Premenstrual syndrome was present in 14 patients, dyspareunia in 14 and avoidance of sexual intercourse due to pain in 12 . 
pain with the cotton swab exam of vulva was determined in two regions in only one individual in the control group. Pain was present at one point in eight patients, at two points in two patients, in three points in four patients and at five points in one patient. Significant variation was determined between the patient and control groups in terms of the $(p<0.001)$ (Table $3)$. The most painful regions at the cotton swab exam of vulva were the 4 and 6 points of the clock.

Correlation analysis revealed moderate correlation between FSFI and VAS pain score $(p=0.023, r=0.463)$, but none with severity of dyspareunia, FIQ or duration of disease. A mild correlation was observed between the pain with the cotton swab exam of vulva and avoidance of intercourse $(p=0.046, r=0.411)$, but none between the pain with cotton swab exam of vulva and FSFI ( $p=0.057, r=0,394)$. Total Brink score was $7.9 \pm 2.3$ in the patients and $11.58 \pm 1.13$ in the controls $(p<0.001)$. Powerful negative correlation was determined between pain with cotton swab exam and total Brink score $(p<0.001, r=-0.575)$ (Table 4).

\begin{tabular}{|c|c|c|c|}
\hline & $\begin{array}{l}\text { Patient } \\
(n=24)\end{array}$ & $\begin{array}{l}\text { Control } \\
(n=24)\end{array}$ & \multirow[t]{2}{*}{ p value* } \\
\hline Variables & Mean \pm SD & Mean \pm SD & \\
\hline Age (years) & $39.00 \pm 5.39$ & $37.29 \pm 4.68$ & 0.175 \\
\hline $\begin{array}{l}\text { Duration of } \\
\text { disease (years) }\end{array}$ & $4.67 \pm 4.47$ & - & - \\
\hline \multirow[t]{2}{*}{ BMI $\left(\mathrm{kg} / \mathrm{m}^{2}\right)$} & $26.77 \pm 6.22$ & $26.14 \pm 4.08$ & 0.984 \\
\hline & n (\%) & n (\%) & p value ** \\
\hline \multicolumn{4}{|l|}{ Smoking status } \\
\hline Smoker & $6(25.0)$ & $6(33.3)$ & \multirow{2}{*}{0.751} \\
\hline Non-smoker & $18(75.0)$ & $16(66.7)$ & \\
\hline \multicolumn{4}{|c|}{ Number of children } \\
\hline None & $2(8.3)$ & $2(8.3)$ & \multirow{4}{*}{0.945} \\
\hline 1 & $6(25.0)$ & $7(29.2)$ & \\
\hline 2 & $10(41.7)$ & $8(33.3)$ & \\
\hline 3 & $6(25.0)$ & $7(29.2)$ & \\
\hline \multicolumn{4}{|c|}{$\begin{array}{l}\text { *Independent samples test, }{ }^{*} \text { *Pearson chi-square, SD: Standard deviation, } \\
\text { BMI: Body mass index }\end{array}$} \\
\hline
\end{tabular}

Table 2. Comparison of sexual functions and pain severity in the patient and control groups

\begin{tabular}{|l|l|l|l|}
\hline Variables & $\begin{array}{l}\text { Patient } \\
(\mathbf{n = 2 4 )}\end{array}$ & $\begin{array}{l}\text { Control } \\
(\mathbf{n = 2 4 )}\end{array}$ & $\begin{array}{l}\mathbf{p} \\
\text { value* }\end{array}$ \\
\hline FSFI & $21.43 \pm 6.46$ & $29.96 \pm 3.71$ & 0.001 \\
\hline VAS dysmenorrhea & $3.67 \pm 3.34$ & $0.88 \pm 1.70$ & 0.003 \\
\hline VAS dyspareunia & $2.50 \pm 2.69$ & $0.63 \pm 1.88$ & 0.006 \\
\hline VAS pain+ & $67.91 \pm 16.21$ & - & - \\
\hline \multicolumn{2}{|l|}{ *Independent-samples Mann-Whitney U, VAS: Visual analogue scale, FSFI: } \\
Female Sexual Function Index
\end{tabular}

\section{Discussion}

Vulvodynia is a significant health problem of uncertain etiology seen in many women. Vulvodynia involves vulvar stinging and a burning persisting for at least 3 months. Many patients find it difficult to speak of this problem, which affects women's daily lives and sexual relations $(9,11)$. Studies have reported that vulvodynia is associated with at least one chronic morbidity, particularly FMS, irritable bowel syndrome and interstitial cystitis $(12,13)$.

Our findings show significantly greater PVD in patients with FMS (62.5\%) compared to the control group (4.1\%), and indicate that patients avoided sexual relations for this reason. Numerous genetic, hormonal, inflammatory, psychological, musculoskeletal and structural causes have been implicated in the etiology of vulvodynia. Pain syndromes with central and peripheral neurogenic mechanisms are also implicated in the etiology. Vulvodynia in patients with FMS may be thought of as a peripheral component of increased pain sensitization $(11,14)$. Some studies have reported that patients with PVD feel greater

\section{Table 3. Genital pain and pain-related intercourse} avoidance in the patient and control groups

\begin{tabular}{|c|c|c|c|}
\hline & $\begin{array}{l}\text { Patient } \\
(n=24)\end{array}$ & $\begin{array}{l}\text { Control } \\
(n=24)\end{array}$ & \multirow[t]{2}{*}{ p value } \\
\hline Variables & n (\%) & n (\%) & \\
\hline \multicolumn{3}{|c|}{ Premenstrual symptoms } & \multirow{3}{*}{$0.039 *$} \\
\hline Yes & $14(58.33)$ & $6(25)$ & \\
\hline No & $10(41.6)$ & $18(75)$ & \\
\hline \multicolumn{3}{|l|}{ Dyspareunia } & \multirow{3}{*}{$0.006 *$} \\
\hline Yes & $14(58.3)$ & 4 & \\
\hline No & $10(41.6)$ & 20 & \\
\hline \multicolumn{3}{|c|}{ Intercourse avoidance } & \multirow{4}{*}{$0.116^{*}$} \\
\hline None & $17(70.8)$ & $22(91.7)$ & \\
\hline Moderate & $4(16.7)$ & $2(8.3)$ & \\
\hline Severe & $3(12.5)$ & $0(0.0)$ & \\
\hline \multicolumn{3}{|c|}{ Pain with cotton swab exam } & \multirow{3}{*}{$<0.001 * *$} \\
\hline Yes & $15(62.5)$ & $1(4.2)$ & \\
\hline No & 9 (37.5) & $23(95.8)$ & \\
\hline
\end{tabular}

Table 4. Correlations with provoked vulvodynia (cotton swab exam) in patients

\begin{tabular}{|l|l|l|}
\multirow{2}{*}{ Variables } & \multicolumn{2}{|c|}{ Cotton swab exam } \\
\cline { 2 - 3 } & $\mathbf{p}$ & $\mathbf{r}$ \\
\hline Intercourse avoidance & $\mathbf{0 . 0 4 6 *}$ & 0.411 \\
\hline Brink score & $<\mathbf{0 . 0 0 1 * *}$ & 0.575 \\
\hline FSFI & $\mathbf{0 . 0 5 7 *}$ & 0.394 \\
\hline $\begin{array}{l}\text { *Spearman correlation, **Kendall correlation, FSFI: Female Sexual Function } \\
\text { Index }\end{array}$
\end{tabular}


pain compared to control groups in non-genital regions (15). Additionally, brain imaging studies of patients with PVD have identified high activation in the insular and frontal cortex throughout application of pressure described as painful (16). Peripheral neurological mechanisms have also been reported to be potentially involved in the etiology in these patients (11). Neural hyperplasia in the vulvar endoderm has been shown in PVD. This is thought to lead to an increase in sensitivity (17). Dyspareunia was determined in 14 (53.8\%) patients in this study. Ghizzani et al. (14) observed PVD in 53.82\% of FMS patients Aydin et al. (18) determined pain in 50\% of patients during sexual intercourse and in $16.8 \%$ of the control group. Another study observed increased sensitivity in $22.6 \%$ of patients and dyspareunia in $30.2 \%$ of patients during vaginal penetration, compared to levels of $14.7 \%$ and $10.9 \%$ in the control group (19). In our study, premenstrual syndrome was determined in $58.33 \%$ of patients and dysmenorrhea in $62.5 \%$. Shaver et al. (19) reported levels of $41.6 \%$ and $37.4 \%$, respectively.

A significant proportion of patients with PVD also exhibited intercourse avoidance behavior $(p=0.046)$. However, there was no correlation between PVD and sexual functions ( $p=0.057)$. Multifactorial causes such as depression, fatigue and diffuse body pain affect the development of sexual dysfunction in patients with FMS. It was not therefore unexpected that PVD should not be associated with sexual dysfunction. The absence of any correlation between severity of dyspareunia and sexual dysfunction supports this view.

Another important finding from this study is that mean Brinks scores were lower in the patient group $(p<0.001)$. In addition, Brink scores decreased as PVD increased ( $p<0.001, r=-0.575)$. Dysfunction in the pelvic floor muscles, such as spasm, impaired contraction and relaxation, decreased strength may occur in patients with vulvodynia $(20,21)$. Although the cause is unclear, there is a widespread view among authors that it occurs secondary to inflammation in the mucosa. Penetration muscle hypertonicity occurs as a result of a defense mechanism developing secondary to painful sexual relations, followed by instability $(22,23)$. According to another view, pelvic muscle dysfunction may be the result of a sensitization process in the mucosa (24), Central sensitization may develop following peripheral sensitization, and pain occurs in extragenital areas. In support of this view, tenderness in patients with vulvodynia has been found not only in the vulva, but also in peripheral regions such as the arm and leg $(15,12)$. One recently published study reported a mean Brink score of 9 in patients with FMS. That study compared patients with pelvic organ prolapse with or without FMS and determined greater pelvic muscle dysfuction in the FMS patients (25). The mean Brink score in our study was $7.9 \pm 2.3$.

\section{Study Limitations}

The main limitation of this study is that the number of volunteers was limited for religious and cultural reasons. Wider studies with more patients are now needed on this subject.

\section{Conclusion}

In conclusion, vulvodynia must be investigated in patients with FMS, the pelvic floor muscles must be examined and potential effects such as sexual dysfunction must not be overlooked. Treatment must be multidisciplinary, and multimodal therapeutic options including biofeedback, electrotherapy and exercise must be tried. An improvement in patients' quality of life can thus be achieved.

\section{Ethics}

Ethics Committee Approval: The Local Ethics Committee of Çanakkale Onsekiz Mart University Faculty of Medicine approved the study and written informed consent was taken from each patient (date: 14.05.2014 no: 2014-09/05).

Informed Consent: It was taken.

Peer-review: Externally peer-reviewed.

\section{Authorship Contributions}

Surgical and Medical Practices: H.R., D.D., F.B., C.Z., Concept: H.R., C.Z., S.O., Design: H.R., D.D., F.B., C.Z., Data Collection or Processing: D.D., S.O., C.Z., Analysis or Interpretation: S.O., C.Z., Literature Search: H.R., D.D., F.B., Writing: H.R.

Conflict of Interest: No conflict of interest was declared by the authors.

Financial Disclosure: The authors declared that this study received no financial support.

\section{References}

1. Wilke WS. New developments in the diagnosis of fibromyalgia syndrome: say goodbye to tender points? Cleve Clin J Med 2009;76:345-52.

2. Geenen R, Jacobs JW. Fibromyalgia: diagnosis, pathogenesis, and treatment. Curr Opin Anaesthesiol 2001;14:533-9.

3. Hawkins RA. Fibromyalgia: a clinical update. J Am Osteopath Assoc 2013;113:680-9.

4. Reed BD, Harlow SD, Sen A, Edwards RM, Chen D, Haefner HK. Relationship between vulvodynia and chronic comorbid pain conditions. Obstet Gynecol 2012;120:145-51.

5. Stockdale CK, Lawson HW. 2013 Vulvodynia Guideline update. J Low Genit Tract Dis 2014;18:93-100.

6. Mercier J, Morin M, Lemieux MC, Reichetzer B, Khalifé S, Dumoulin C. Pelvic flor muscles training to reduce symptoms and signs of vulvovaginal atrophy: a case study. Menopause 2016;23:816-20.

7. Burckhardt CS, Clark SR, Bennett RM. The fibromyalgia impact questionnaire: development and validation. I Rheumatol 1991;18:728-33.

8. Rosen R, Brown C, Heiman J, Leiblum S, Meston C, Shabsigh R. The Female Sexual Function Index (FSFI): a multidimensional selfreport instrument for the assessment of female sexual function. J Sex Marital Ther 2000;26:191-208.

9. Petersen $C D$, Lundvall L, Kristensen E, Giraldi A. Vulvodynia. Definition, diagnosis and treatment. Acta Obstet Gynecol Scand 2008;87:893-901

10. FitzGerald MP, Burgio KL, Borello-France DF, Menefee SA, Schaffer J, Kraus $S$, et al. Pelvic-floor strength in women with incontinence as assessed by the brink scale. Phys Ther 2007;87:1316-24.

11. Bornstein J, Goldstein AT, Stockdale CK, Bergeron S, Pukall C, Zolnoun D, et al. 2015 ISSVD, ISSWSH, and IPPS Consensus Terminology and Classification of Persistent Vulvar Pain and Vulvodynia. J Sex Med 2016;13:607-12.

12. Giesecke J, Reed BD, Haefner HK, Giesecke T, Clauw DJ, Gracely $\mathrm{RH}$. Quantitative sensory testing in vulvodynia patients and 
increased peripheral pressure pain sensitivity. Obstet Gynecol 2004; 104:126-33.

13. Pukall CF, Baron M, Amsel R, Khalifé S, Binik YM. Tender point examination in women with vulvar vestibulitis syndrome. Clin J Pain 2006;22:601-9.

14. Ghizzani A, Di Sabatino V, Suman AL, Biasi G, Santarcangelo EL, Carli G. Pain Symptoms in Fibromyalgia Patients with and without Provoked Vulvodynia. Pain Res Treat 2014;2014:457618.

15. Pukall CF, Binik YM, Khalifé S, Amsel R, Abbott FV. Vestibular tactile and pain thresholds in women with vulvar vestibulitis syndrome. Pain 2002;96:163-75.

16. Pukall CF, Strigo IA, Binik YM, Amsel R, Khalifé $S$, Bushnell MC. Neural correlates of painful genital touch in women with vulvar vestibulitis syndrome. Pain 2005;115:118-27.

17. Weström LV, Willen R. Vestibular nerve fiber proliferation in vulvar vestibulitis syndrome. Obstet Gynecol 1998;91:572-6.

18. Aydin G, Başar MM, Keleş I, Ergün G, Orkun S, Batislam E. Relationship between sexual dysfunction and psychiatric status in premenopausal women with fibromyalgia. Urology 2006;67:156-61.
19. Shaver JL, Wilbur J, Robinson FP, Wang E, Buntin MS. Women's health issues with fibromyalgia syndrome. J Womens Health (Larchmt) 2006;15:1035-45.

20. White G, Jantos M, Glazer H. Establishing the diagnosis of vulvar vestibulitis. J Reprod Med 1997;42:157-60.

21. Glazer HI, Jantos M, Hartmann EH, Swencionis C. Electromyographic comparisons of the pelvic floor in women with dysesthetic vulvodynia and asymptomatic women. J Reprod Med 1998;43:959-62.

22. Reissing ED, Brown C, Lord MJ, Binik YM, Khalifé S. Pelvic floor muscle functioning in women with vulvar vestibulitis syndrome. J Psychosom Obstet Gynaecol 2005;26:107-13.

23. Wesselmann U. Neurogenic inflammation and chronic pelvic pain. World J Urol 2001;19:180-5

24. Zolnoun D, Hartmann K, Lamvu G, As-Sanie S, Maixner W, Steege J. A conceptual model for the pathophysiology of vulvar vestibulitis syndrome. Obstet Gynecol Surv 2006;61:395-401.

25. Adams K, Osmundsen B, Gregory WT. Does fibromyalgia influence symptom bother from pelvic organ prolapse? Int Urogynecol J 2014;25:677-82. 